\title{
An Assessment of Auditor's Independence on the Quality of Financial Reporting: Evidence from Lagos State Parastatals
}

\author{
*Adesola Olajumoke Okunola \\ School of Illantigement \& Social Sciences, Pinl-Itlintic Iniversity, Liagos, ligeriit
}

\begin{abstract}
This study investigated the effect of auditor's independence on the financial reporting quality of Parastatals in Lagos state, Nigeria. A survey was conducted to gather data on auditor's independence and a content analysis procedure was adopted to extract secondary data from the audited financial statement of the parastatals. Data were analyzed using binary logistic regression. The findings show that when an auditor alienates his personal interest from audit and his ability to issue a qualified audit opinion where necessary, have a statistically significant effect on improving both the fundamental and enhanced qualitative characteristics of financial reporting (FQC and EQC). Hence, the more an auditor allows his personal interests to becloud his judgement, the lower both the FQC and $E Q C$ of financial reporting. The outcome of reliance on the work of the internal auditors and auditor's rotation gave an inconclusive result. Therefore, rotation of auditors and the reliance on the findings of internal auditors promote the relevance and how faithfully represented the financial reporting are, while the EQC has no effect on auditor's independence. The study recommended that parastatals must place a premium on promoting auditors' independence in order to minimize audit failure and the credibility attached to the financial reports.

Keywords: Financial reporting quality, auditor's independence, enhanced and fundamental qualitative characteristics, parastatals, binary logistic regression

JEL: H83, M41, M42
\end{abstract}

The public sector represents the largest sector of the economy of all nations; it employs the largest labor force and directs the biggest part of the country's financial and non-financial resources (Chowdhury, 1996). The evidence and information gathered in the public sector may mostly not be financial and requires subjective judgment by the auditor. Public trust can only be confidently achieved when both financial and non-financial resources reposed in the auditor have been effectively managed through systematic audit practice procedures. The public expects responsible public officers to manage public funds with absolute integrity and accountability.

Auditing in the public sector has been challenged severally at the international, national, and state levels as a result of the inadequacy in the information provided by the audited financial statements (Nikoloyuk et al., 2005). Public policy and decisions are made on this deficient annual report, which consequently leads to poor decision implementation on the part of the government (Odia, 2014). The primary objective of financial reporting is the provision of adequate financial information on an existing 
entity for taking an economic decision. The International Accounting Standard Board ([IASB], 2008) asserts that financial reporting is expected to provide adequate information about the financial position of an entity useful to users in making an economic decision. However, it has been revealed that there were a series of untimely deaths of many organizations due to financial scandals which were borne out of lack of auditor independence and transparency, accountability, and poor financial management. The case of Cadbury Nigeria Plc. and it's over 40-year auditor, Akintola Williams Deloitte and Touche, who were indicted for failing to apply professional skepticism and due diligence in the course of rendering professional services, was the pinnacle of this fall.

Similar to what was obtainable in the Nigerian corporate sector, the public sector is not in any way immune to audit failure. However, suspected audit failures are concealed on the premise of classified information or the culture of secrecy of government information despite the Freedom of Information Act 2011, which is aimed at making public records and information freely accessible to citizens.

Several audit practices in the public sector that ought to be a celebrated case of audit failure were concealed but for the reason of classified information. This questions the integrity and independence with which the audited accounts are prepared. The independence of an auditor is put to test by its capability to report the discovery of any breach in the client's financial statement. Similarly, the independence deployed in the course of carrying out the audit is a function of how versatile and knowledgeable the auditor is. The undue reliance on the work of the resident auditors, personal interest or gain, and prolonged tenureship might pose a threat to the auditor's independence. The ability to manage these will likely enhance the degree of confidence placed in the auditor and the quality of financial reporting, without exposing its opinion to public suspicion. The financial statement is a trusted communication tool for the various stakeholders, hence the independence with which it is prepared determines the worth placed on its quality. From the foregoing, it is therefore imperative to discover for the Nigerian public sector whether the auditor's independence implies relevant, faithfully represented, and enhanced quality financial reporting.

A plethora of studies have examined the auditor's independence on several variables, such as auditor's competence (Abdul et al., 2014), audit fees (Abdul-Rahman et al., 2017), non-audit services (Abdulaziz, 2009), corporate governance (Adelopo, 2010), and bank stability (Adekunle and Asaolu, 2013). However, the current study proxied auditor's independence on auditor's personal interest, reliance on internal auditor's findings, auditor's rotation as well as the ability of the auditor to issue a qualified audit opinion. Studies using this combination of proxies are relatively scanty, as evidenced in previous literature. Second, different instruments have been used in prior studies to measure financial reporting quality, such as accrual models (Jones, 1991; Dechow et al., 1995); value relevance models (Choi et al., 1997 ; Barth et al., 2001; Nicholas and Wahlen, 2004) and specific 


\section{Okunola}

elements in annual reports (Beretta and Bozzolan, 2004). This study improves the methodology of these studies by adopting both the use of primary and secondary data. Questionnaires were used to gather information on auditor's independence while the quality of financial reporting was operationalized using both the enhanced and fundamental quality of financial reporting similar to the works of Braam and Beest (2013); Puspitasari and Yurisandi (2015), Mbobo and Ekpo (2016) and Kisaku (2017). Finally, to the best of the researcher's knowledge, previous studies focused on the private sector such as manufacturing, banking, and auditing firms (e.g., Nwanyanwu, 2017; Adekunle and Asaolu, 2013; Okolie, 2014); the non-availability of similar studies centring on the public sector with an emphasis on Lagos State parastatals is a gap to be filled.

Following the introductory section, section 2 provides both the theoretical and empirical review. Section 3 describes the data and methodology used. Section 4 presents and discusses the empirical results, while sections 5,6 , and 7 conclude the study, discusses the policy implications and future directions.

\section{LITERATURE REVIEW}

\section{Theoretical Underpinnings}

\section{- Agency theory}

Historically, agency theory emanates with human civilization arising from doing business with the view of maximizing personal interests (Panda and Leepsa, 2017). This theory finds its roots in the study of Berle and Means (1932), as cited by Adelopo (2010) on the separation of ownership of a firm from its management. Smith (2011) and Kivisto (2007) postulated that the landmark achievement of the theory is credited to the work of Jensen and Meckling (1976) and Fama and Jensen (1983), where they documented that agency problems will emanate where the principal employs the service of an agent to execute some assignment in his stead.

From the public sector perspective, the Office of the Lagos State Auditor-General is the supreme audit institution (SAI) which serves as the external auditor for all government establishments in the state. Therefore, the external auditors employed to audit the parastatals report to the Office of the Auditor General of Lagos State before the audit report is signed. The SAI is independent of the political agents' influence, as they report directly to the House of Assembly, who review the audit report and ensure that law breakers are invited and interrogated by the Public Accounts Committee (PAC). The parties concerned are allowed to defend themselves and, when found guilty, will be brought to justice. This act reinforces the trust the governed have in the government. The House of Assembly here is the 
principal, and the SAI is acting in her stead, while the agents are the various parastatals carved out to perform specialized and distinct roles outside the normal ministerial functions. The adoption of the theory in the public sector context suggests a wider and broader perspective of the principal-agent relationship. This implies that agency relationships within the public sector are expanded to accommodate at various levels of government.

The public sector audit supports the principal-agent hypothesis, according to which appointed and elected office holders (agents) are expected to report to the public (principals) on a regular basis on funds and resources entrusted to their care, if they have been used wisely for the intended purpose (DeSimone, 2017). Looking at the Nigeria public sector, for example, there is a notion that government business is nobody's business (Uzuh, 2006); this encourages a nonchalant attitude and non-accountability on the part of those saddled with the responsibility of managing government resources. Consequentially, a principal-agent problem exists where government officials (agents) pursue their inordinate goals at the expense of the citizens (principal). The multiplicity of agency problems in the public sector arises as a result of the complexity of the agent-principal relationship, such as the citizens or voters as the principal with multiple agents such as the president, the senate, house of assembly, public accounts committees, auditor general, accountant general, governors, ministers, commissioners, just to mention a few. Agency problem arises at different levels such as between the President and the Senate, Senate and the House of Assembly, Public Accounts Committee and the Auditor-General of the Federation, the Auditor-General of the Federation and the Accountant-General of the Federation, Accountant-General of the Federation and the accounting officers, accounting officers and directors within the public service, between the senior and junior cadre in the service and ultimately, between the President and the people he governs (citizens). This misalignment of interest and the pessimistic role of the agents increase the need for sound audit practices within the public sector in order to boost citizens' trust and confidence in the sector.

\section{-Comfort Theory}

The birth of the theory is rooted in the medical profession. Orlando (1961) elucidates that one of the key responsibilities of a nurse is to establish a good relationship with her patients with a view to enhancing comfort creation. The imported theory was firstly applied in the auditing profession by Collins (1981) where he opined that the conduct and conclusion of an audit involves an orderly approach and an emotional procedure which forms a social order that leads to comfort. Pentland (1993) abstracted that deceitful financial information is changed to reflect its true and fair position through diligent appraisal of the financial statement, thereby producing comfort to the users. In other words, the applicability of professional care and skill on the part of the auditor help in diagnosing 


\section{Okunola}

correctly and the provision of appropriate solution thereby providing comfort for the users of the public sector financial statement.

\section{Empirical Review on Auditor's Independence and Financial Reporting Quality}

Genre of researchers across the globe has studied the effect of auditor's independence on the quality of financial reporting. He and Chen (2021) investigated the impact of audit rotation on companies' information disclosures and it signaling effect on auditors' strategies of listed companies in Taiwan from 2004 to 2016. The study differentiates between mandatory and voluntary auditor's rotation. In effect, the study concludes that a company under a mandatory auditor rotation chooses an industry expertise auditor to be their successor audit partners compared to a voluntary rotation auditor. This eventually reduces rotation costs since audit partners are usually rotated rather than the audit firm. With the use of industry specialists, this consequentially improves the quality of the financial reports and the auditor's independence as well as their signaling effect on the users.

Martani et al. (2021) provide new evidence on the impact of audit tenure and rotation on audit quality. Their study concludes that an insignificant relationship exists between audit tenure and audit quality. It was discovered that mandatory audit firm rotation for non-big 4 audit firms is very necessary to improve the quality financial reporting (QFR) since they are constrained by the limited number of partners. Unlike the big 4, QFR will improve with audit partner rotation because they have a sufficient number of partners to rotate with varied skills, competence, and experience.

Cular et al. (2020) examined the effect of an internal auditor's engagement in risk management consulting on external auditors' reliance decisions. Findings from the study indicate that the external auditor's reliance on the internal audit supportive function is at its peak when the internal auditor renders risk management services under the supervision of a strong audit committee. However, reliance on the work of the internal auditor is largely dependent on the perception of the external auditor as to its independence and the objectivity of its report.

Yakubu and Williams (2020) examined the effect of auditor's independence on the quality of audit. They opined that where auditors exert more efforts in conducting a rigorous audit, it promotes independence and attracts higher fees. Similarly, mandatory auditor's rotation promotes independence and, therefore, improves both financial report and audit quality.

Bassey et al. (2020) tested whether the interaction between auditors' independence impacts the audit quality. The outcome of the study shows that audit fees have a significantly negative effect on audit quality, while auditor's rotation and audit tenure have a negative influence on the quality of the audit. This suggests that low audit fees beyond the acceptable benchmark will significantly reduce the 
audit quality, while auditor's rotation and audit tenure do not improve the quality of audit in any way.

Marques et al. (2019) conducted a qualitative study on auditor's independence and the perceptions of auditors. The outcome of the study suggests that auditors' non-audit services and tenure are major factors impeding auditor's independence, while rotation and exposure to litigation are considered as incentives to improve independence and consequently the quality of financial reporting. The conclusion lacks empirical findings; hence the outcome cannot be generalized.

Argento et al. (2018) examined the reliance on the work of internal auditors (IAs) by external auditors. The study shows that the professionalism and independence of IAs might be questioned. Therefore, relying on the work of IAs may affect audit quality. However, the study concludes that the external auditor's professionalism prevails over the emotions, communication, and body chemistry of the IAs.

Nwanyanwu (2017) analyzed financial reporting and audit quality in Nigeria through a survey design. The outcome of the study establishes that there exists a statistically significant positive relationship between the auditor's independence and the reliability of financial reports at a 0.01 level of significance. The study draws evidence from auditing firms, which makes the results inadequate to generalize, especially in the public sector. The study also lacks theoretical underpinnings.

This position is in consonance with Animasaun and Adegbite (2016), who concluded that the longer the tenure of an audit firm, the greater the extent of both financial and non-financial bonding (economic bonding hypothesis), which poses a major threat to auditor's independence. The study is flawed on the premise that it stated several theoretical underpinnings without identifying and applying any to the study. The use of diagrams along with the tabular schedule makes the study cumbersome and unnecessarily bulky.

The findings of Babatolu et al. (2016) are consistent with those of Adeyemi and Okpala (2011). The outcome projects that there is a positively significant relationship between audit fees, audit firm rotation, and audit quality. Audit firm rotation curtails familiarity threat and the shorter the auditor's tenure, the more valuable the audit is likely to be.

Tepalagul and Lin (2014) conducted comprehensive academic research concerning auditor independence and audit quality. The study was analyzed based on articles that were published from nine (9) leading auditing journals in the period of 1976 to 2013. It is drawn out from the study that four main issues can pose a threat to auditor's independence. They are client importance and its affiliation with the audit firm, auditor tenure, and the provision of non-audit services. The research is conceptual and does not have empirical evidence; however, it is useful for boosting the literature on auditor independence.

Okolie (2014) contends the outcome by supporting the expertise hypothesis, that the longer the 


\section{Okunola}

better as it checkmates the opportunistic behaviors of the management. Empirical evidences were extracted from quoted companies. As a result, the study's findings cannot be used to form a broad opinion about the public sector. The use of discretionary accrual affects judgment because it is exposed to human manipulation. Likewise, the study lacks theoretical foundations to compliment the research output. Supportively, Amake and Okafor (2012) argued that when tenureship is prolonged, it is not an indication that the auditor's independence will be compromised, rather brings about the display of expertise in the approach to audit assignment.

Adeyemi and Okpala (2011) investigated the impact of an auditor's independence on financial reporting in Nigeria. The results show that the quality of external audits would be weakened where auditors sourced loans from their client organizations, and as such, the auditor's independence is impaired. The outcome was criticized on the grounds that it had no theoretical underpinnings to support the findings.

The study has developed two null hypotheses arising from the literature above on the auditor's independence and the quality of financial reporting:

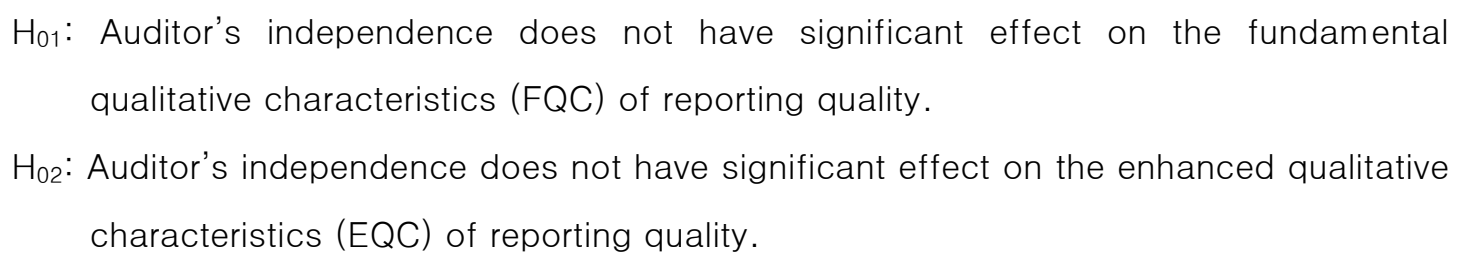

\section{METHODOLOGY}

\section{-Sample and Procedure}

The study adopted both survey research through questionnaire administration and content analysis of the audited financial statements. The survey focused mainly on investigating the effect of the auditor's independence on the financial reporting quality of some selected Lagos State Parastatals. Data on the dependent variables were extracted from the published audited financial statements of sixty-three (63) audited financial statements of the selected parastatals for six (6) consecutive years, totaling 378 audited financial statements. The dependent variable adopts Nijmegen Center for Economics (NiCE) instrument as developed by Beest, Braam and Boelens (2009) and IASB (2008) quality indicators and adopted by Braam and Beest (2013), Puspitasari and Yurisandi (2015), Mbobo and Ekpo (2016) and Kisaku (2017); however, with slight modifications to meet the requirements of Lagos State its usage is scarcely found in the public sector. The study considered four items from R1 to R4 for relevance (R); four items from FR1 to FR4 for faithful representation (FR); three items from V1 to V3 for verifiability 
(V), four items from U1 to U4 for understandability (U); four items from C1 to C4 for comparability (C) and one item for timeliness $(T)$. Relevance and faithful representation represent the fundamental qualitative characteristics (FQC) while verifiability, comparability, understandability, and timeliness make up the enhanced qualitative characteristics (EQC). The dependent variable qualities were analysed by answering YES or NO as to the compliance of the audited financial statements.

While the questionnaire was administered to six (6) senior officers from each of the selected parastatals, totaling three hundred and fifteen (378) respondents, but only two hundred and ninetyseven (297) were found valid. The study sample on auditor's independence was selected using purposive sampling, with four questions asked for each of the proxies. The independent variable was proxied on auditor's personal interest, reliance on internal auditors, qualified audit opinion, and auditor's rotation.

This study covered the activities of selected parastatals within the public sector of Lagos State from 2014-2019. This period was selected on the premise that Lagos state public service adopted the Audit Law of 2011 in 2012, which repealed the 64-years old 1956 Audit Act of the Federal Republic of Nigeria. The State began compliance with International Public Sector Accounting Standards (IPSASs) in 2016 (accrual accounting), although necessary apparatus had been deployed to ensure the State's compliance with IPSAS since 2014 (Alamu, 2014; Oyewobi, 2019). The choice of Lagos was also influenced by the fact that it is the commercial nerve-center of Nigeria with the highest foreign and domestic debt of over $\$ 1.45$ billion (Debt Management Office, 2018) and ranks first as the state with the highest internally generated revenue (IGR) of N268.2b (National Bureau of Statistics, 2018).

\section{-Model}

The principal-agent relationship as posited by the agency theory provided the hypothesis that connects the auditor's independence with the quality of financial reporting. The binary logistic regression (BLR) was employed to analyze the effect of auditor's independence on the quality of financial reporting. The BLR was chosen because it helps in establishing the relationship that subsists between binary or dichotomous dependent variables as abstracted from the work of Ezenwoke (2017). This study, however, deviated from Ezenwoke (2017) by focusing on the auditor's personal interest, reliance on the work of the internal auditor, issuance of a qualified audit report, and auditor's rotation.

The BLR model is presented as follows:

$$
\begin{aligned}
& \mathrm{FQC}_{\mathrm{it}}=\beta_{0}+\beta_{1} \mathrm{APIN}_{\mathrm{it}}+\beta_{2} \mathrm{RINA}_{\mathrm{it}}+\beta_{3} \mathrm{QAOP}_{\mathrm{it}}+\beta_{4} \mathrm{AUDR}_{\mathrm{it}}+\mu_{\mathrm{it}} \cdots \cdots \text { (i) } \\
& \mathrm{EQC}_{\mathrm{it}}=\alpha_{0}+\alpha_{1} \mathrm{APIN}_{\mathrm{it}}+\alpha_{2} \mathrm{RINA}_{\mathrm{it}}+\alpha_{3} \mathrm{QAOP}_{\mathrm{it}}+\alpha_{4} \mathrm{AUDR}_{\mathrm{it}}+\varepsilon_{\mathrm{it}} \cdots \cdots \text { (ii) }
\end{aligned}
$$

where: 


\section{Okunola}

FQC depicts Financial Reporting Quality

EQC represents Enhanced Qualitative Characteristics

APIN is Auditor's Personal Interest

RINA represents Reliance on Internal Auditors

QAOP stands for Qualified Audit Opinion

AUDR depicts Auditor's Rotation

The $\beta_{0}$ and $\alpha_{0}$ are intercepts; $\beta_{1}-\beta_{4}, \alpha_{1}-\alpha_{4}$ are coefficients of the explanatory variables. The ' $i$ ' represents the cross section of parastatals, and the ' $t$ ' indicates the year under consideration, while $\mu$ and $\varepsilon$ are the stochastic error terms.

The outcome of the first and second hypothesis testing was based on whether the Wald test result established the overall contribution and importance of each of the independent variables. The predictors that contribute significantly to the predictive power of the model are statistically significant at $p<.05$. The odds ratio (Exp (B)) implies the probability that an event will occur compared to the probability of its non-occurrence. Factors with values higher than one indicate that the odds are increased; those with values less than one indicate that the odds are decreased. This implies that the greater the auditor's independence (auditor rotation, personal interest, reliance on internal auditors, ability to issue a qualified audit report, and auditors' rotation), the greater the likelihood that fundamental and enhanced financial reporting quality will be improved. The Hosmer and Lemeshow $(\mathrm{H}-\mathrm{L})$ test is the most reliable test of goodness of model fit. The test indicates a poor fit where the results of the $\mathrm{H}-\mathrm{L}$ test is less than .05 . The Cox and Snell $\mathrm{R}$-square and Nagelkerke R-square values suggest the extent of variation in the dependent variable explained by the model (Pallant, 2013).

\section{RESULTS}

\section{-Demographic Statistics of Respondents}

Table 1 (see Appendix-I) contains the demographic distribution of the respondents as well as the response rate. The targeted population of this study was the seventy-five (75) Lagos State Parastatals, out of which sixty-three (63) of them were selected for the administration of the questionnaire. Of the three hundred and seventy-eight (378) respondents selected, to which questionnaires were administered, only two hundred and ninety-seven (297) questionnaires were returned valid, and these represent a 78.6 percent response rate. Twelve (12) questionnaires representing 3.2 percent were returned partially completed which makes it inappropriate for analysis. Some respondents explained that as far as they are concerned, information relating to the public sector is meant to be classified while some gave the excuse of work overload. Sixty-nine (69) questio- 
nnaires, amounting to 3.5 percent of the questionnaires were also not returned. Mugenda and Mugenda (2009) asserted that for a questionnaire to be fit for examination and reporting, the response rate of 50 percent and above is considered adequate. 60 percent is described as good, 70 percent is considered very good, while above 70 percent is considered excellent. In view of these, the response rate of 78.6 percent is considered excellent for analysis and reporting of this study. The demographic distribution of the respondents by cadre shows that $140(47.1 \%)$ of the respondents were senior internal auditors, while $125(42.1 \%), 25(8.4 \%), 2(0.7 \%)$, and $5(1.7 \%)$ were chief internal auditors, assistant directors (audit), auditor general and others in that order, respectively. This suggests that the majority of the audit staff of Lagos State Parastatals fall between Internal Auditor II and Chief Internal Auditor which have the highest percentages of 47.1 percent and 42.1 percent, respectively, while only a few staff are at Director's cadre.

The genders of the respondents were 52.2 percent male and 47.8 percent female, respectively. This is an indication that there is the predominance of male staff in Lagos State parastatals and maybe the trend in the Lagos State Civil Service. The respondent gender rate is consistent with the study of Gberevbie (2009) which identified the staff strength of Lagos State Civil Service to be 58 percent male and 42 percent female. However, considering the unusable and non-returned questionnaire totaling $81(21.4 \%)$, it may be difficult to generalize as this may skew towards favoring a particular gender. The academic qualifications of the respondents indicated that 11 (3.7\%) respondents were high school leavers, 21 (7.1\%) represents Ordinary National Diploma (OND) holders, 81 (27.3\%) respondents have Higher National Diploma (HND), 147 (49.5\%) represents the majority with Bachelor of Science (B.Sc.) while 37 (12.5\%) have an either a Master of Science (M.Sc.), Masters in Business Administration (MBA) or Masters of Art (MA), respectively. Consequentially, this suggests that the majority of the respondents were sufficiently educationally qualified which enabled them to understand the contents of the questionnaire more thoroughly and are more likely to provide reasonable responses.

\section{-Descriptive Statistics of the Respondents}

Table 2 (see Appendix-II) presents the mean and standard deviation of the responses of the auditor's independence proxies (four questions asked each) and its effect on the financial reporting quality of Lagos State Parastatals. The mean value of 3.14 in question 1 implies that the majority of the respondents are inclined towards nearly agreed state that auditors' interest might impair their deliverables in the discharge of the audit assignment. Also, question 2 which revealed the mean value of 3.65 is an indication that the ability of the auditor to give a qualified audit opinion signals that they are independent of influences with a mean value greater than 3 . The mean value of less than the 


\section{Okunola}

average in question 3 (RINA) is an indication that the reliance on the work of the internal auditor will negatively affect the independence with which the financial statements are audited. Lastly, the mean value of 4.21 in question 4 implies that most of the respondents agreed that auditor's rotation improves auditor's independence (mean $>3$ ).

Generally, the means of all the questions are above 3 except one, indicating that if all the questions raised are carefully considered and factored into the parastatals, they will promote the independence with which the auditor approaches his assignment. The standard deviation of the question shows the variability of the auditor's independence to be between $0.5385-0.6650$ on the scale of $1-5$. This implies that the risk of non-adherence to all the questions is less than 3 . Therefore, it can be concluded that the auditors are relatively independent of influences within the parastatals but for reliance on the internal auditors with a mean value of 2.10 which is less than the average.

\section{DISCUSSION}

\section{Auditor's Independence and the Fundamental Qualitative Characteristics}

Table 3 (see Appendix-III) shows the interrelationship between auditor's independence and the fundamental qualitative characteristics of financial reporting. The Wald test results establish the overall contribution and importance of each of the independent variables. The predictors that contribute significantly to the predictive power of the model are statistically significant at $p<.05$. The table below shows the direction of the relationship at negative $(-v e)$ B values of -.396 and -.034 respectively, which indicate that the greater the auditor's personal interest, the less likely the quality of financial reporting will be. Also, the greater reliance on internal auditors, the less likely the quality of financial reporting will be. The positive (+ve) B values of .479, .199 and .163 indicate the higher the auditor's independence, the more likely the fundamental financial reporting quality is improved. Also, the higher the chances an audit report is qualified, the more likely the fundamental financial reporting quality is improved. Similarly, an increase in auditor's rotation will more likely improve the fundamental quality of financial reporting.

The table reflects that an auditor's personal interest is less likely to improve the fundamental financial reporting quality. The odds ratio of the variable is .673 , a value less than 1 with a $p=.001$ implies that the more the auditor's personal interest, the poorer the fundamental financial reporting quality. For every extra unit of the auditor's personal interest, the odds of the fundamental quality of financial reporting decrease by a factor of .673, all other factors being equal. This is consistent with the studies of Adeyemi and Okpala (2011) and Animasaun and Adegbite (2016), who opined that the personal benefit of the auditor impairs their independence and, consequently the financial reporting 
quality. This position is also supported by the agency theory, which opines that agent (auditors) seek to maximize their personal utility contrary to the principals' (shareholders') expectations (Adelopo, 2010). Still, in the same vein, qualified audit opinion and auditor's rotation with odds values of 1.220 and 1.177 ( $p=.004$ and .046) suggest a higher effect on the fundamental quality of financial reporting. The result indicates that high tendencies to express a qualified audit opinion and the auditor's rotation are vital in improving the fundamental financial reporting quality. The ability of the auditor to issue a qualified report without fidgeting or fright suggests that the report will likely soothe and comfort the financial and non-financial losses of the principal, the outcome also support the comfort theory. The study by Adeyemi and Okpala (2011) supports the outcome as their study suggests that a long tenure audit- client relationship may mar independence thereby eroding the $F R Q$. Reliance on internal auditors as well as selection is $.967(p=.592)$. The odds ratio of .967 for reliance on internal auditors indicates that for every additional reliance on internal auditors, the fundamental financial reporting quality was .967 times less likely to reflect the true position of the financial report.

The result of the Hosmer-Lemeshow $(\mathrm{H}-\mathrm{L})$ test is significant at 0.101 , which is above the minimum fit of 0.05 (Pallant, 2013), this support the model as being worthwhile. The Cox and Snell R-square $\left(C \& S R^{2}\right)$, and Nagelkerke $R$-square $\left(N R^{2}\right)$ values indicate the amount of variation in the dependent variable explained by the model (Pallant, 2013). C\&SR and $N R^{2}$ are described as the pseudo-R square statistics rather than the true $\mathrm{R}$-square values in multiple regression output. The values of C\&SR ${ }^{2}$ and $N^{2}$ are 47.5 percent and 51.3 percent, respectively, this indicates that between 47.5 percent and 51.3 percent of the variation in the dependent variable is explained by the predictor variables while the remaining 52.5 percent and 48.7 percent are explained by other variables not captured in this model.

\section{Auditor's Independence and the Enhanced Qualitative Characteristics}

Table 4 (see Appendix-IV) shows the outcome of the interrelationship between auditor's independence and the enhanced qualitative characteristics of financial reporting. The auditor's personal interest, with an odds ratio of 0.254 , is less than 1 , which is a pointer to a lower probability of producing a high quality fundamental financial report. The outcome of the auditor's personal interest aligns with the findings of Adeyemi and Okpala (2011), who suggest that auditor's personal interest reduces the quality of financial reporting. The outcome also supports the agency theory, as pointed out by Albrecht (2008), that agents are self-motivated and self-preserved, leading to asymmetry of information between the agent and the principal.

In the same vein, reliance on internal auditors, the ability to issue a qualified audit opinion, and auditor's rotation with odds values of $1.783,1.211$ and 1.186 respectively, suggest a significant impr- 


\section{Okunola}

ovement in the fundamental financial reporting quality. The result of the reliance on the internal auditors supports the findings of Kewo and Afiah (2017) which opined that reliance on internal audit improves the financial reporting quality. Similarly, the outcome of the auditor's rotation aligns with the suggestion of Amake and Okafor (2012), Okolie (2014), Animasaun and Adegbite (2016), and Babatolu et al. (2016), that the shorter the auditor's tenureship, the better the fundamental quality of financial reporting. The researcher's study on auditor's rotation leading to an improvement in the $F R Q$ is hinged on the fact that the Lagos State Audit Act permits auditors to audit a parastatal for a maximum of three years. This promotes independence and freedom from economic bonding between the client and auditor. A lesson to be learnt from the crisis experienced as a result of undue auditclient prolonged relationships between Enron and Arthur Andersen for seventeen years in the US, as well as Cadbury Nigeria Plc and its forty-years auditor, Akintola Williams Deloitte and Touche. The outcome of the study further suggests that the consciousness on the part of the client that the auditor can issue a qualified opinion enhances the financial reporting quality. The findings support Chiang and Lin (2012) who opined that those auditors are more conscious of their reputation, thus they become more conservative in expressing their audit reports after Enron's collapse.

The direction of the relationship at negative $(-v e)$ B value of -1.369 indicates that the higher the auditor's personal interest, the lesser the quality of enhanced financial reporting will be. The positive (+ve) B values of .998, .579, .192 and .171 implies that the higher the auditor's independence, the greater the reliance on internal auditors, and the more the chances of reporting a qualified opinion, the more likely the financial reporting quality is enhanced in terms of verifiability, comparability, understandability and timelines. Similarly, an increase in auditor's rotation will more likely improve the enhanced quality of financial reporting, thereby streamlining undue relationships and bonding.

The result of the $\mathrm{H}-\mathrm{L}$ test is significant at 0.189 , which is above the minimum fit, supports our model as being worthwhile. The variation in the dependent variable is explained by the predictor variable between 33.2 percent and 48.3, respectively, in line with the values of $C \& S R^{2}$ and $N^{2}$, while 76.8 percent and 51.7 percent are explained by other variables.

\section{CONCLUSION}

The study has analyzed the efficacy of auditor's independence in improving the quality of financial reporting in the public sector of Lagos State using survey research through questionnaire administration and extraction of data from audited financial statements of 63 parastatals of Lagos State spanning through 2014 to 2019 financial years as summarized in Table 5 (see Appendix-V). The study concludes that auditor's independence has a significant positive effect on both the fundamental and 
enhanced quality of financial reporting. Similarly, the enhanced and fundamental quality of the financial report is upheld where the auditor's integrity is not in question, as well as when he does not put his personal interest before the audit. Likewise, the ability of the SAl to issue a qualified audit opinion where necessary signals the autonomy with which the account is audited.

The research further exposes the fact that the reliance on the work of the internal auditor plays a major role in improving the relevance and how faithfully represented the quality of the financial reporting in the Lagos State Parastatals. Conversely, the reliance on the internal auditor's findings does not have any significant effect on the understandability, verifiability, comparability, and timeliness with which the financial report is prepared. In other words, the reliance on the internal auditor's findings will not, in any way, enhance the ability of the users to access the report within the stipulated time frame, its understanding, verifiability and comparability. Lastly, it is determined from the outcome of the study that auditor's rotation is positive and significant in promoting how relevant and faithfully represented the financial reporting is, while the prolonged tenureship of the external auditor does not, in any way, enhance the verifiability, comparability, timeliness, and the understandability of financial reporting.

\section{IMPLICATIONS}

The auditing scandals in Nigeria and other parts of the globe have stepped up the interest in investigating the effect of auditor's independence and its effect on the quality of financial reporting from the public sector perspective. Empirical and literature-based research have been conducted in order to determine how auditor's independence can improve the financial reporting quality in the public sector. The study reveals that the independence of auditors contributes significantly to the financial reporting quality, which is measured with relevance, faithful representation, understandability, verifiability, comparability, and timeliness, even in the public sector. If the measures recommended to improve the auditor's independence within the public service are implemented, it is submitted that the profession will reduce public criticism against the auditor and its role, and society will be able to respect, rely on, and make informed and credible decisions on the financial reports of parastatals within the State.

\section{LIMITATIONS AND FUTURE DIRECTIONS}

In spite of the bold attempt made in this study towards establishing the effect of auditor's independence on the quality of financial reporting, the study is not void of limitations. The duration of 6 years (2014 to 2019) covered is considered short. This period was covered, however, because of 


\section{Okunola}

non-availability of data for the prior period and non-preparation of audited accounts for the parastatals as due. Another shortcoming of this study is in the fact that Ministries, Departments and Agencies (MDAs) are not considered for analysis, and this is so because some of the variables used are not available for the MDAs. It is also noteworthy that the study focusses on Lagos State only without considering the remaining 35 states of the Federal Republic of Nigeria. The current study is centered on the auditor's independence and the financial reporting quality within the Lagos State Parastatals. However, an avenue for further research is to look at the effects of corporate governance practices and financial reporting quality within the public sector context. A comparative analysis of the quantitative financial reporting quality can be carried out to determine whether a similar or a contradictory result will be arrived at. Another untapped area, as shown in the earlier studies, indicates that further empirical studies can be conducted to determine the relationship between the enhanced and fundamental qualitative characteristics of financial reporting and the overall quality of financial reporting. Lastly, there exists another avenue to investigate the area of uncovering fraud and forensic investigation within the public sector.

\section{REFERENCES}

Abdulaziz, A. I. (2009). Non-audit services and auditor independence. The case of Saudi Arabia. Unpublished doctoral dissertation, Victoria University.

Abdul, H., Sutrisno, T., Rosidi, \& Achsin, M. (2014). Effect of Competence and Auditor Independence on Audit Quality with Audit Time Budget and Professional Commitment as a Moderation Variable. International Journal of Business and Management Invention, 3(6): 64-74.

Abdul-Rahman, O. A., Benjamin, O. A., \& Olayinka, O. H. (2017). Effect of audit fees on audit quality: Evidence from cement manufacturing companies in Nigeria. European Journal of Accounting, Auditing and Finance Research, 5(1): 6- 17.

Adekunle, A. A., \& Asaolu, T. (2013). An empirical investigation of the financial reporting

practices and banks' stability in Nigeria. Kuwait Chapter of Arabian Journal of Business and Management Review, 2(5): 157180.

Adelopo, I. (2010). The Impact of corporate governance on auditor independence: In UK listed companies. Unpublished doctoral dissertation, De Montfort University.

Adeyemi, S. B., \& Okpala, O. (2011). The impact of audit independence on financial reporting: Evidence from Nigeria. Business and Management Review, 1(4): 9-25. https://ir.unilag.edu.ng/handle/123456789/2319

Alamu, I.T. (2014). Adoption of international public sector accounting standards. Compliance based workshop at Olabisi Onabanjo University.

Albrecht, C. O. (2008). International fraud: A management perspective. Unpublished doctoral dissertation, Universitat Ramon Llull. https://www.academia.edu/9496390

Amake, C. C., \& Okafor, C. (2012). Auditors Independence, Auditors' tenure and audit firm size in Nigeria. Research Journal of Finance and Accounting, 3(10): 137- 142.

Animasaun, R. O. \& Adegbite, I. A. (2016). Auditors' independence and accountability of Federal Higher Institutions in Ogun State. Research Journal of Finance and Accounting, 7(2):188-203.

Argento, D., Umans, T., Håkansson, P. \& Johansson, A. (2018). Reliance on the internal auditors' work: experiences of Swedish external auditors. Journal of Management Control, 29, 295-325. https://doi.org/10.1007/s00187-018-00272-7

Babatolu, A. T., Osasrere, A. O., \& Emmanuel, U. (2016). Auditor's independence and audit quality: A study of selected Deposit Money Banks in Nigeria. International Journal of Finance and Accounting, 5(1): $13-21$. https://doi.org/10.5923/j.ijfa.20160501.02

Barth, M., Beaver, W. \& Landsman, W. (2001). The Relevance of the value relevance literature for financial accounting standard setting: Another view. Journal of Accounting and Economics, 31, 77-104. https://doi.org/4_20140516025703.21

Bassey, E.B., Omini, E.U., Aminu, O., Etore, U.A., \& Archibong, S.E. (2020). Auditors independence and audit quality in Nigeria. Critical Reviews, 7(17): 624-635. https://doi.org/10.31838/jcr.07.17.86 
Beest, F. V., Braam, G., \& Boelens, S. (2009). Quality of Financial Reporting: Measuring Qualitative Characteristics. Nijmegen Center for Economics (NiCE), Institute for Management Research, Radboud University. The Netherlands. Retrieved on 10 January 2019 from http://www.ru.nl/nice/workingpapers.

Beretta, S. \& Bozzolan, S. (2004). A Framework for the Analysis of Firm Risk Communication. The International Journal of Accounting, 39(3): 265-288. https://doi.org/10.1016/j.intacc.2004.06.006

Berle, A., \& Means, G. (1932). The Modern Corporation and Private Property. New York: Macmillan.

Braam, G., \& Beest, F. V. (2013). Conceptually-Based Financial Reporting Quality Assessment: An Empirical Analysis on Quality Differences Between UK Annual Reports and US 10-K Reports (No. NiCE13-07).

Chiang, H. \& Lin, S. (2012). Effect of auditor's judgement and specialization of their differential opinion between semiannual and annual financial reports. Global Journal of Business Research, 6(4): 1-22.

Choi, B., Collins D.W. \& Johnson W.B. (1997). Valuation implications of reliability differences: The case of Non person Post retirement Obligations. The Accounting Review, 72(3): 351-383.

Chowdhury, R. R. (1996). Audit expectation gap in the public sector of Bangladesh, Unpublished doctoral dissertation, University of Dundee.

Collins, R. (1981). On the Microfoundations of Macrosociology. American Journal of Sociology, 86(5): 984-1014.

Cular, M. Slapnič ar, S \& Vuko, T. (2020). The effect of internal auditors' engagement in risk management consulting on external auditors' reliance decision. European Accounting Review,1-23. https://doi.org/10.1080/09638180.2020.1723667

Debt Management Office (DMO) (2018). National Debt Management Framework (2018-2022). Available at: https://www.dmo.gov.ng/publications/other-publications/national-debt-management-framework/2706-national-debtmanagement-framework-2018-2022/file

Dechow, P.M., Sloan, R.G. \& Sweeny, A.P. (1995). Detecting earnings management. The Accounting Review, 70(2):193-225. https://doi.org/10.12691/jfe-7-3-4.

DeSimone, S. (2017). Internal audit and financial reporting quality in the Public Sector. College of The Holy Cross, Department of Economics, Faculty Research Series, 18-02.

Ezenwoke, O.A. (2017). Organisational determinants and e-accounting system implementation in micro and small enterprises (MSES) in South-West, Nigeria. An Unpublished PhD Dissertation in Accounting, Covenant University, Ota.

Fama, E., Jensen, M. (1983). Separation of ownership and control. Journal of Law and Economics 26, $301-325$. http://www.jstor.org/stable/725104

Gberevbie, D. E. (2009). Personnel recruitment and retention strategies in Lagos State Civil Service of Nigeria. African Research Review, an International Multi-Disciplinary Journal, Ethiopia. 3(3): 226-243.

He, L.-J. \& Chen, J. (2021). Does mandatory audit partner rotation influence auditor selection strategies? Sustainability 13, 112. https://doi.org/10.3390/ su13042058

International Accounting Standards Board [IASB]. (2008). Exposure draft on an improved conceptual framework for financial reporting: The objective of financial reporting and qualitative characteristics of decision-useful financial reporting information. London.

Jensen, M. \& Meckling, W. (1976). Theory of the Firm: Managerial Behavior, Agency Costs, and Capital Structure. Journal of Financial Economics 3, 305- 360.

Jones, J. (1991). Earnings management during import relief investigations. Journal of Accounting Research, 29, $193-228$. https://doi.org/10.2307/2491047

Kewo, C.L \& Afiah, N.N. (2017). Does the quality of financial statement affected by internal control system and internal audit? International Journal of Economics and Financial Issues, 7(2): 568-573.

Kisaku, J. M. (2017). Impact of financial reporting frameworks on the quality of not-for-profit financial reports. Walden Dissertations and Doctoral Studies. 4644.

Kivisto, J. (2007). Agency theory as a framework for government university relationship. Unpublished doctoral dissertation. University of Tampere

Marques, I.S.S., Major, M.J., \& Da Veiga, M.D. (2019). Auditor independence: A qualitative study of the perceptions of auditors. International Journal of Accounting and Taxation, 7(1): 15-25. https://doi.org/10.15640/ijat.v7n1a2

Martani, D., Rahmah, N.A., Fitriany, F., \& Anggraita, V. (2021). Impact of audit tenure audit rotation on the audit quality: Big 4 vs non big 4. Cogent Economics and Finance, 9(1): 1-19. https://doi.org/10.1080/23322039.2021.1901395

Mbobo, M. E., \& Ekpo, N. B. (2016). Operationalising the qualitative characteristics of financial reporting. International Journal of Finance and Accounting, 5(4):184- 192. https://doi.org/10.5923/j.ijfa.20160504.03

Mugenda, O. M., \& Mugenda, A. G. (2009). Social Science Research. Nairobi: Acts Press National Bureau of Statistics (2018). https://www.nigerianstat.gov.ng/ (Accessed 07, August 2019).

Nicholas, D., \& Wahlen, J. (2004). How do earnings numbers relate to stock returns? A review of classic accounting research with updated evidence. Accounting Horizons, 18(4): 263-286. https://doi.org/10.2308/acch.2004.18.4.263

Nikoloyuk, G. M., Marche, S. \& McNiven, J. (2005). E-commerce impact on Canadian public sector audit practice, International Journal of Public Sector Management, 18(1): 83-95.

Nwanyanwu, L. A. (2017). Audit quality practices and financial reporting in Nigeria. International Journal of Academic Research in Accounting, Finance and Management Sciences, 7(2): 145-155. http://dx.doi.org/10.6007/IJARAFMS/v7-i2/2879

Odia, J. O. (2014). Performance auditing and public sector accountability in Nigeria: The roles of supreme audit institutions (SAIs); Asian Journal of Management Sciences and Education,3(2): 102-109.

Okolie, A. O. (2014). Auditor tenure, auditor independence and accrual-based earnings management of quoted companies in Nigeria. European Journal of Accounting Auditing and Finance Research, 2(2): 63-90. 


\section{Okunola}

Orlando, I. (1961). The dynamic nurse-patient relationship function, process and principles. New York: G P Putnam's Sons

Oyewobi, I.A. (2019). Implications of international public sector accounting standards adoption and financial report quality in Lagos State. International Journal of Advance Research, 7(1):1124-1129. http://dx.doi.org/10.21474/IJAR01/8430

Panda, B., \& Leepsa, N. (2017). Agency theory: Review of theory and evidence on problems and perspectives. Indian Journal of Corporate Governance, 10(1): 74-95. http://dx.doi.org/10.1177/0974686217701467

Pallant, J. (2013). SPSS survival manual: A step-by-step guide to data analysis using IBM SPSS. $5^{\text {Th }}$ Edition. Mc Graw Hill Publisher.

Pentland, B.T (1993). Getting Comfortable with the Numbers: Auditing and the Micro-Production of Macro-order. Accounting, Organizations and Society, 18(7/8): 605- 620. doi:10.1016;0361-3682(93)90045-8

Puspitasari, E., \& Yurisandi, T. (2015). Financial reporting quality - Before and after IFRS adoption using NiCE qualitative characteristics measurement. In 2nd Global Conference on Business and Social Science, 211, 644- 652.

Smith, T.R. (2011). Agency theory and its consequences. A study of the unintended effect of agency theory on risk and morality. Unpublished M.Sc. dissertation. Copenhagen Business School.

Tepalagul, N., \& Lin, L. (2014). Auditor independence and audit quality: A literature review. Journal of Accounting, Auditing and Finance, 3(4): 1-21. https://doi.org/10.1177/0148558X14544505

Uzuh, J. (2006). All you need to know about auditing principles and practices. Supreme Konsults, Yaba, Lagos.

Yakubu, R., \& Williams, T. (2020). A theoretical approach to auditor independence and audit quality. Corporate Ownership and Control, 17(2): 124-141. https://doi.org/10.22495/cocv17i2art11 


\begin{tabular}{|c|c|c|}
\hline Response Rate & Frequency & Percentage (\%) \\
\hline Valid & 297 & 78.6 \\
\hline Invalid & 12 & 3.2 \\
\hline Not returned & 69 & 18.3 \\
\hline Total & 378 & 100.00 \\
\hline Rank/ Cadre of the Respondents & Frequency & Percentage (\%) \\
\hline $\begin{array}{l}\text { Internal Auditor II- Senior Internal } \\
\text { Auditor }\end{array}$ & 140 & 47.1 \\
\hline $\begin{array}{l}\text { Principal Internal Auditor- } \\
\text { Chief Internal Auditor }\end{array}$ & 125 & 42.1 \\
\hline $\begin{array}{l}\text { Assistant Director (Audit)- } \\
\text { Director (Audit) }\end{array}$ & 25 & 8.4 \\
\hline Auditor General (LS) & 2 & 0.7 \\
\hline Others & 5 & 1.7 \\
\hline Gender of the Respondents & Frequency & Percentage $(\%)$ \\
\hline Female & 142 & 47.8 \\
\hline Male & 155 & 52.2 \\
\hline Academic Qualifications & Frequency & Percentage $(\%)$ \\
\hline High School & 11 & 3.7 \\
\hline OND & 21 & 7.1 \\
\hline HND & 81 & 27.3 \\
\hline B.Sc. & 147 & 49.5 \\
\hline MBA/MSc. /MA & 37 & 12.5 \\
\hline
\end{tabular}

Source: Author's computation

Table 1. Demographic Distribution of the Respondents 


\begin{tabular}{|c|c|c|c|c|c|c|c|c|}
\hline SN & Questions & $\begin{array}{l}5 \\
(\%)\end{array}$ & $\begin{array}{l}4 \\
(\%)\end{array}$ & $\begin{array}{l}3 \\
(\%)\end{array}$ & $\begin{array}{l}2 \\
(\%)\end{array}$ & $\begin{array}{l}1 \\
(\%)\end{array}$ & Mean & SD \\
\hline 1 & APIN & $\begin{array}{l}124 \\
(41.8)\end{array}$ & $\begin{array}{l}93 \\
(31.3)\end{array}$ & $\begin{array}{l}16 \\
(5.4)\end{array}$ & $\begin{array}{l}42 \\
(14.1)\end{array}$ & $\begin{array}{l}22 \\
(7.4)\end{array}$ & 3.14 & 0.6500 \\
\hline 2 & QAOP & $\begin{array}{l}78 \\
(26.3)\end{array}$ & $\begin{array}{l}121 \\
(40.7)\end{array}$ & $\begin{array}{l}36 \\
(12.1)\end{array}$ & $\begin{array}{l}41 \\
(13.8)\end{array}$ & $\begin{array}{l}21 \\
(7.1)\end{array}$ & 3.65 & 0.6035 \\
\hline 3 & RINA & $\begin{array}{l}88 \\
(29.6)\end{array}$ & $\begin{array}{l}94 \\
(31.6)\end{array}$ & $\begin{array}{l}43 \\
(14.5)\end{array}$ & $\begin{array}{l}45 \\
(15.2)\end{array}$ & $\begin{array}{l}27 \\
(9.1)\end{array}$ & 2.10 & 0.5610 \\
\hline 4 & AUDR & $\begin{array}{l}152 \\
(51.2)\end{array}$ & $\begin{array}{l}96 \\
(32.3)\end{array}$ & $\begin{array}{l}24 \\
(8.1)\end{array}$ & $\begin{array}{l}9 \\
\text { (3) }\end{array}$ & $\begin{array}{l}16 \\
(5.4)\end{array}$ & 4.21 & 0.5385 \\
\hline
\end{tabular}

Source: Author's computation

Key:1=Strongly Disagree, 2=Disagree, 3=Undecided, 4=Agree, 5=Strongly Agree

Table 2. Descriptive Statistics of Components of Auditor's Independence 


\begin{tabular}{lccllll}
\hline Indicator & B & S.E. & Wald & $d f$ & Sig. & $\operatorname{Exp(B)}$ \\
\hline Auditor's Personal Interest & -.396 & .072 & 29.778 & 1 & $.000^{\circ}$ & .673 \\
Reliance on Internal Auditors & -.034 & .063 & .287 & 1 & .592 & .967 \\
Qualified Audit Opinion & .199 & .070 & 8.196 & 1 & $.004^{\circ}$ & 1.220 \\
Auditor's Rotation & .163 & .082 & 3.964 & 1 & $.046^{\circ}$ & 1.177 \\
Constant & .322 & .523 & .379 & 1 & .538 & 1.380 \\
\hline
\end{tabular}

\begin{tabular}{ll} 
C\&S R & 0.475 \\
NR $^{2}$ & 0.513 \\
H-L Test & 0.101 \\
\hline Source: Author's Computation & \\
B= logistic regression coefficient; S.E.= standard error; Wald= Wald statistics; $d f=$ degree of freedom; \\
Sig.= significance level; Exp(B)= odds ratio
\end{tabular}

Table 3. Coefficients Binary Logistic Regression Results of Auditor's Independence on Fundamental Qualitative Characteristics of Financial Reporting 


\begin{tabular}{|c|c|c|c|c|c|c|}
\hline Indicator & B & S.E. & Wald & $d f$ & Sig. & $\operatorname{Exp}(B)$ \\
\hline Auditor's Personal Interest & -1.369 & .112 & 149.570 & 1 & .001 & .254 \\
\hline $\begin{array}{l}\text { Reliance on Internal } \\
\text { Auditors }\end{array}$ & 0.579 & .095 & 37.300 & 1 & .001 & 1.783 \\
\hline Qualified Audit Opinion & 0.192 & .092 & 4.348 & 1 & .037 & 1.211 \\
\hline Auditor's Rotation & 0.171 & .100 & 2.922 & 1 & .087 & 1.186 \\
\hline Constant & 0.925 & .671 & 1.904 & 1 & .168 & 2.523 \\
\hline $\mathrm{C} \& S \mathrm{R}^{2}$ & 0.475 & & & & & \\
\hline $\mathrm{NR}^{2}$ & 0.513 & & & & & \\
\hline H-L Test & 0.101 & & & & & \\
\hline
\end{tabular}

Table 4. Binary Logistic Regression Results of Auditor's Independence on Enhanced Qualitative Characteristics of Financial Reporting 


\begin{tabular}{|c|c|c|c|c|}
\hline Hypothesis & Description & Indicators & Sig. & Decision \\
\hline $\mathrm{H}_{01}(\mathrm{a})$ & \multirow{2}{*}{$\begin{array}{l}\text { Auditor's personal interest does not have a } \\
\text { significant effect on the financial reporting } \\
\text { quality }\end{array}$} & APIN on FQC & .001 & Reject \\
\hline $\mathrm{H}_{01}(\mathrm{~b})$ & & APIN on EQC & .001 & Reject \\
\hline $\mathrm{H}_{02}(\mathrm{a})$ & \multirow{2}{*}{$\begin{array}{l}\text { Reliance on internal auditor's findings } \\
\text { does not have any significant effect on } \\
\text { financial reporting quality }\end{array}$} & RINA on FQC & .001 & Reject \\
\hline $\mathrm{H}_{02}(\mathrm{~b})$ & & RINA on EQC & .592 & Accept \\
\hline $\mathrm{H}_{03}(\mathrm{a})$ & \multirow{2}{*}{$\begin{array}{c}\text { Issuance of qualified audit opinion does } \\
\text { not significantly affect financial reporting } \\
\text { quality }\end{array}$} & QAUR on FQC & .004 & Reject \\
\hline $\mathrm{H}_{03}(\mathrm{~b})$ & & QAUR on EQC & .037 & Reject \\
\hline $\mathrm{H}_{04}(\mathrm{a})$ & \multirow[t]{2}{*}{$\begin{array}{l}\text { Auditor's Rotation does not significantly } \\
\text { affect financial reporting quality }\end{array}$} & AUDR on FQC & .046 & Reject \\
\hline $\mathrm{H}_{04}(\mathrm{~b})$ & & AUDR on EQC & .087 & Accept \\
\hline
\end{tabular}

Table 5. Summary of Results 